\title{
Applying landscape principles to fire hazard reduction
}

\author{
Craig Loehle* \\ National Council for Air and Stream Improvement, Inc. (NCASI), 552 S Washington Street, Suite 224, Naperville, IL 60540, USA
}

Received 12 December 2003; received in revised form 31 March 2004; accepted 27 April 2004

\begin{abstract}
Fire spreads in a specifically spatial manner, which suggests the applicability of percolation models to the risk reduction problem. It is shown that under fairly general conditions a threshold exists below which a landscape becomes essentially fireproof. Arranging treated acres into a grid, analogous to bulkheads on a ship, drastically reduces the acreage that must be treated to achieve a fireproof condition. Such compartmentation of the landscape yields a much higher leverage (ratio of acres saved to acres treated). Certain landscape features create updrafts that spread fire particularly far. Treating fuels in such areas yields high leverage. Fire shadow effects were replicated by the simulation and showed a possible mechanism for amplifying treatment effectiveness. Either fuel reduction programs or commercial forestry can be used to achieve hazard reduction without excessive costs if spatial aspects of fire spread are taken into account.
\end{abstract}

(C) 2004 Elsevier B.V. All rights reserved.

Keywords: Fuels management; Forest fire; Silviculture; Percolation model; Compartmentation

\section{Introduction}

Catastrophic fires in the western US are a growing concern. These fires have often exceeded 100,000 acres, and 1,000,000 acres in some cases. When destroyed buildings, degraded water quality, loss of wildlife habitat, costs of firefighting, and risk to human life are added to the losses to the wood products industry, the costs can be seen to be truly massive (e.g., Armstrong and Cumming, 2003). Such large fires in many (but not all) cases result from uncharacteristic fuel loads (Agee, 1998; Moore et al., 1999; Hessburg et al., 2000; Hessburg and Agee, 2003). Because of the current risk that very large fires will consume towns, destroy entire wildlife preserves, and take many lives, it is certain that society would

\footnotetext{
*Tel.: +1-630-579-1190; fax: +1-630-579-1195. E-mail address: cloehle@ncasi.org (C. Loehle).
}

prefer that such fires be reduced in size, severity, and frequency. This is true even in regions where large fires are "normal" (e.g., in the Canadian boreal forest). The reduction in risk being considered here does not mean going back to total suppression policies of the past, and does not preclude restoring natural fire regimes to open forest types such as ponderosa pine.

What is currently known about fire behavior has not proved sufficient to provide solutions to the fire hazard problem. Methods exist for reducing fire hazards, most notably opening up the canopy, reducing ladder fuels, and burning the understory (Hummel et al., 2001; Fiedler and Keegan, 2003; McIver et al., 2003), although active management can also be effective in forests where politics allow commercial forestry to occur. These techniques can be shown to reduce fire hazard at the stand level (Omi and Martinson, 2002; Pollet and Omi, 2002; Fiedler and Keegan, 2003). The problem is that creating a "firesafe" forest (e.g., Agee, 
2002) can be costly beyond current funding levels (e.g., Finney and Cohen, 2003; Lynch and Mackes, 2003).

A few authors have suggested the idea of fuel breaks, and some such breaks have been used in forests (Hirsch et al., 2001; Finney and Cohen, 2003). In a fuel break, a strip of forest is typically thinned from below and underburned. Such a treatment may convert a crown fire into a ground fire while passing through the fuel break, but the fire may reenter the crowns as it leaves the break. Thus, fuel breaks alone only succeed in slowing fire spread (Finney and Cohen, 2003). These ideas are promising but need a more systematic application to be effective.

Landscape ecology can make a major contribution to this topic. Fire spreads in a specifically spatial manner. As such, it is a sort of percolation process. Cellular (percolation) models of fire spread can produce simulated fire patterns that closely resemble real fire patterns (e.g., Clarke et al., 1994; Von Niessen and Blumen, 1986). Thus, even though not realistic enough for fire management during active fires or for exact simulation, it is likely that percolation theory can provide insights into fire behaviors and fire control strategies in general. Herein, simple models are used to illustrate three key ideas: leverage, thresholds, and compartmentation. Leverage is the idea that a single acre of fuel reduction can protect additional acres. Thresholds are well known in percolation models and occur in the context of fire spread as well. Below the threshold percentage of high-fuel stands, the forest is essentially fireproof (in the sense that crown fires are limited and fire fighting efforts in the forest are successful). With compartmentation, fuel reduction is not performed randomly in space, but in some sort of pattern that blocks fire spread. The goal of the models used here is to illustrate these general ideas, not to provide exact simulations.

\section{Methods}

A simple cellular model of fire spread was used. Grid cells were defined to be forest stands or areas sufficiently large that it would be rare for fire to jump over them under low-wind conditions. Fire spread is thus to nearest neighbors only (this assumption is relaxed below). Fire is initiated with a single lightning strike to five cells in the middle of the map. Fires are allowed to burn for 20 days. This represents the common situation that big fires are usually not put out by human intervention but by a change in the weather. Each cell burns for 1 day, ignites neighbors for the next day's fire, and then goes out (time could of course be scaled differently). The probability $P$ that a stand is ignited by a burning neighbor varies with stand condition. All stands are initially in a high-risk category $(P=0.7)$. With silvicultural treatment (patch cutting, thin and underburn, or other technique), which includes firefighting activities, $P$ is reduced to zero. That is, it is assumed that either a treated stand cannot carry a fire, or that the fire would be a surface fire that fire fighters could control. It is well known that fuel builds up with stand age (Whelan, 1995; Li et al., 1997; Casagrandi and Rinaldi, 1999; Turner et al., 1999; Schoenberg et al., 2003). Similarly, in dry forest such as ponderosa pine (Pinus ponderosa), thinned, burned, or open forest may not carry a fire (Friederici, 2003; Parsons and Van Wagtendonk, 1996; Van Wagtendonk, 1995; Whelan, 1995). The map is sufficiently large $(50 \times 50$ cells $)$ that a fire burning for 20 time units cannot escape it. To incorporate stochastic effects, six runs are made for every scenario and the mean area burned is computed. Cell size is large enough that a ground fire cannot jump over a cell (spot), making fire spread conform to the percolation formalism. Cells may thus be larger than the typical "stand" used in forest management. The effect of fuel treatment was simulated by randomly treating cells on the map at various levels from 5 to $50 \%$ of the map.

A case was considered where some parts of the map send out burning brands ("spotting") to greater distances than the nearest neighbor. This case was constructed by designating a "ridge" running diagonally from lower left to upper right. While burning, each cell on this ridge sends out five burning brands randomly in all directions according to a Normal $[0,4]$ distribution (where the mean is in terms of distance from the burning cell and the variance is units of number of cells). Spotting is a major problem in mountainous terrain or under windy conditions (Foster, 1976; Vines, 1981).

The concept of compartmentation is illustrated next. For given percentages of the map to be treated, the treated cells are laid out in increasingly fine grids 


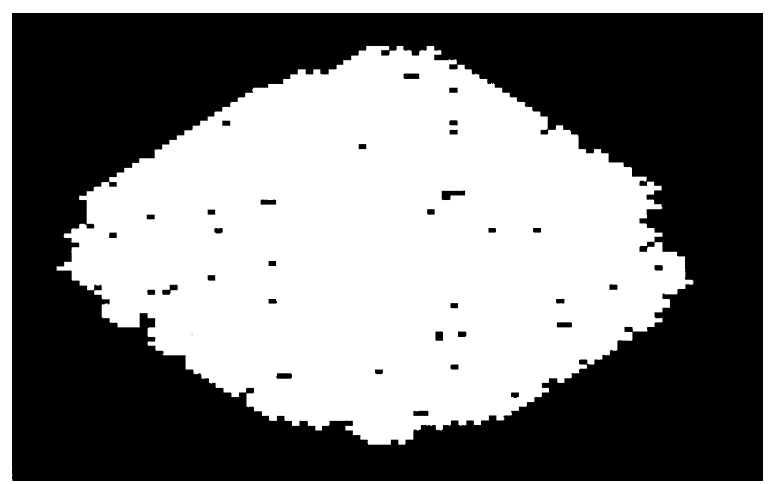

Fig. 1. Typical burn for an untreated $50 \times 50$ map. $P=0.7$ for all cells.

rather than at random. They thus define untreated compartments surrounded by firebreaks. This is analogous to the use of bulkheads on a ship.

\section{Results}

Using the stated parameters, a typical simulated burn on a forest with no treated stands creates a fire that nearly covers the map (Fig. 1). As the extent of treated stands is increased, fire size decreases (Fig. 2). Random treatment produces results similar to the offset treatment design studied by Finney (2001). A notable characteristic of this treatment-response curve is a threshold at about 30\% treatment where the landscape is essentially fireproof. At this point, fires are all kept small. The threshold point will depend on assumptions. If untreated stands have a $P$ value higher than 0.7 or treated stands are not fireproof $(P \neq 0)$, then the threshold will be higher. For example, if $P=1$ for untreated stands (they all burn), then the threshold is about 0.45 , but the curve has a similar shape (not shown). The existence of thresholds is thus a general feature of such a percolation process.

Compartmentation has a dramatic effect on acres burned, which is, of course, why firefighters put in fire breaks. Here, the fire breaks are created by forest management and are intended to be much wider than a traditional firebreak, which is typically inadequate for a crown fire (Hirsch et al., 2001). For the simulation (Fig. 3), all treated acres are put into a grid in the compartmentation case. The effect is to reduce the threshold from 0.30 to 0.11 (Fig. 3). Thus a much smaller degree of treatment is necessary if the treated stands are arranged in a grid. With spotting, some jumping of bulkheads occurs, so the threshold is increased to 0.2 (not shown), but bulkheads are still better than random placement of treated acres. It should be noted that by tying bulkheads into fireproof landscape features such as lakes and agricultural land, thresholds can be reduced even further.

The concept of leverage is illustrated by considering how many acres are protected per acre treated. The noridge, no-bulkhead, $0 \%$ treated case is the base for comparison (Fig. 1). Reductions in acres burned are computed from this base and are divided by acres treated to obtain a benefit ratio at various levels of fuel reduction (Fig. 4). The ratio is not exact unless the whole map has time to burn. We can see that the

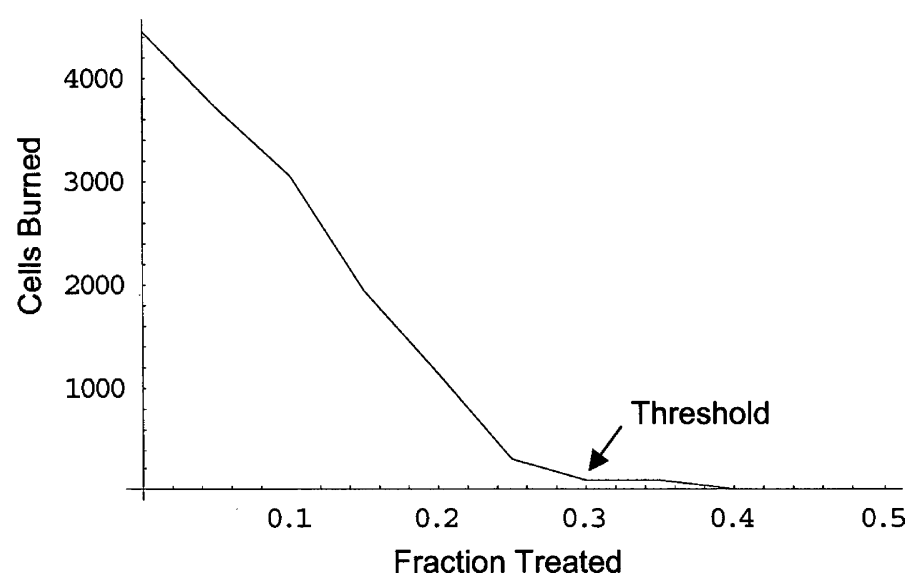

Fig. 2. Effect of random placement of treated cells $(P=0)$ from 0.0 to 0.5 , showing threshold. 


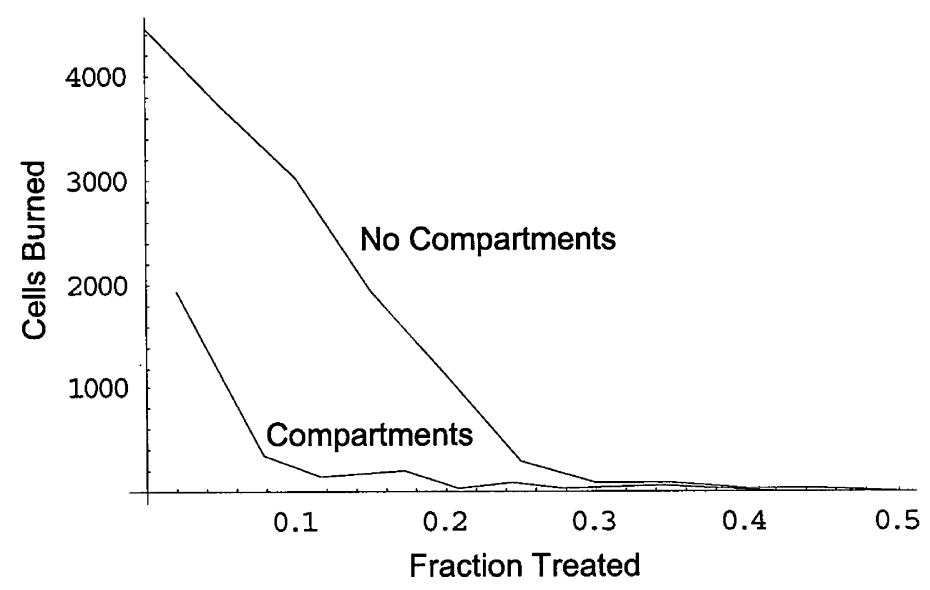

Fig. 3. Effect of compartmentation on cells burned.

benefits of random placement of treated acres is largely flat (constant benefit ratio) with a value near 1.5. This means that treated acres act as a brake on fire spread, as well as protecting the treated acres themselves. By contrast, the bulkhead case has a ratio above 5 at 0.1 treatment level. This indicates much greater leverage (or efficiency) by using compartments (bulkheads). It is interesting to note that with over about $25 \%$ of the map treated the random placement and compartmentation strategies produce nearly identical results. This is because on average random placement divides the landscape into similarly sized untreated blocks above this level. If we consider the case with ridges, a strategy that reduces fuels only on the ridge line achieves a leverage above 11 (a value specific to

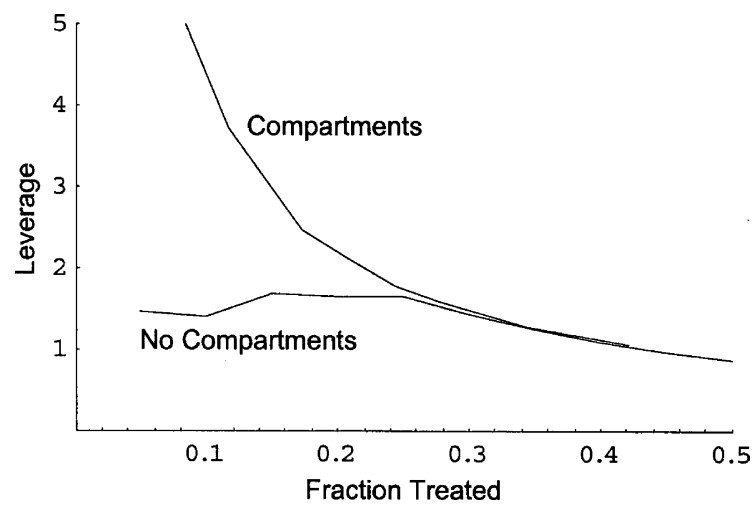

Fig. 4. Leverage (protected/treated) for the no-ridge case, comparing random and compartmentation strategies for treatment. the assumptions used here, not a universal value). Thus the highest leverage points in this system are those locations where fire spreads farther than usual by spotting, such as ridge lines, high fuel locations, or the heads of steep canyons where updrafts are created. Leverage is a useful concept for conducting economic analyses of silviculture or fuel reduction activities.

Leverage has an interesting interaction with wind. Assuming wind that is steady but not too strong, the probability of spread is higher in one direction than in others (directed percolation, Von Niessen and Blumen, 1986) but we can still assume that fire cannot jump over treated stands. This situation was simulated. In Fig. 5a, with $10 \%$ of the landscape treated, the omnidirectional spread case (the wind is shifting) (Fig. 5b) shows a low leverage of 1.32 , which means that some acres are protected by the random configuration of treated acres. If there is a wind, however, this situation changes (Fig. 5c), and fire shadows are created, which are areas downwind of treated areas in which fire does not readily enter from the sides. Such shadows have been simulated with percolation type models (Clarke et al., 1994) and using more realistic models (Finney, 2001). In this case, the leverage is much higher, at 2.97 acres protected for each acre treated. The reason is that even treated areas that are not directly connected act connected if they are offset slightly. Consider that the shadow behind a treated cell may line up with a nearby treated cell, which then makes the fire shadow wider in a cumulative fashion (see also Finney (2001)). This is how such wide fire shadows were 


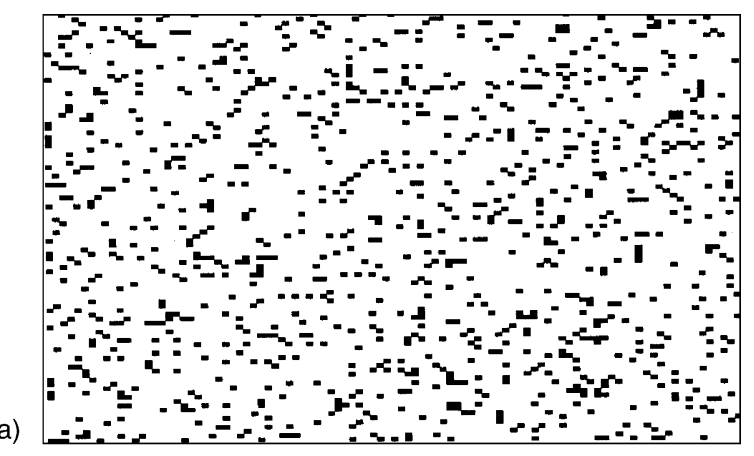

(b)

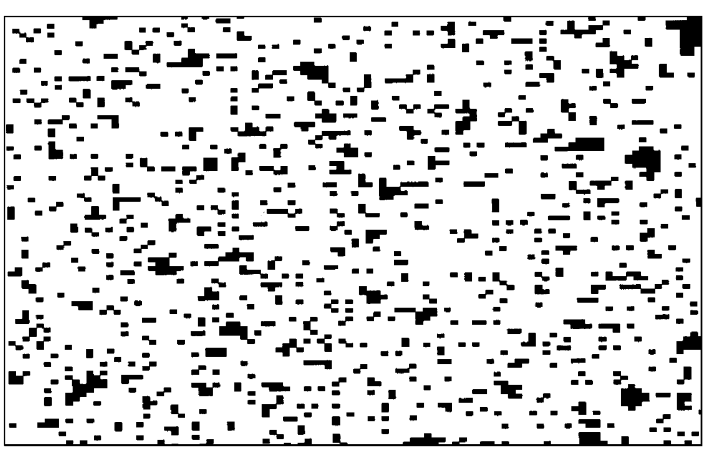

(c)

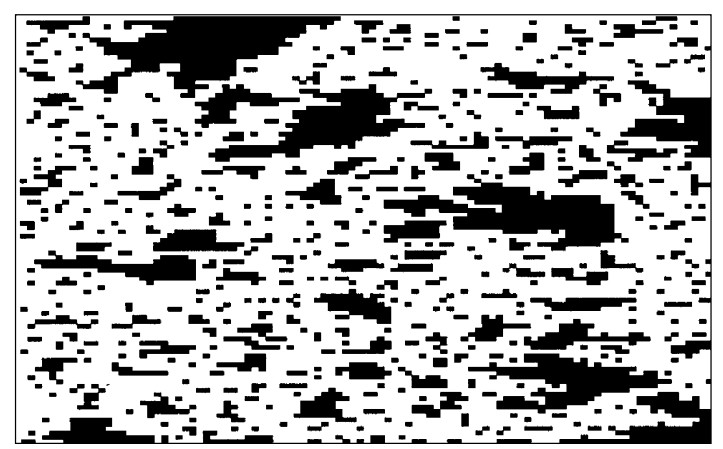

Fig. 5. Effect of wind on fuel reduction treatment effectiveness, with wind blowing from left to right and fire ignition along left border of map. (a) Map showing $10 \%$ of the landscape treated (black cells). (b) After entire map burns with omnidirectional fire spread. Black cells are unburned. Leverage is 1.32 acres saved for each one treated. (c) After entire map burns with wind direction from left to right, showing fire shadows (black). Leverage is 2.97 acres saved for each one treated.

formed in Fig. 5c. We can imagine that such landscape treatment could also effectively retard the creation of firestorm effects in which fires create their own winds, updrafts, and even tornadoes, as also noted by Finney
(2001). This could be tested with models, if any exist that are sufficiently realistic.

There is evidence to support the simulation results. A study in Canada that compared fire histories in areas with different development histories showed that fragmentation of the forest by agriculture (a fireproof land type) has probably reduced the size of fires (Lefort et al., 2003). In the huge McCall (Idaho) fire of 1997, the fire twice burned downslope onto commercial timberland, where it was stopped with little loss of timber, whereas on Forest Service land it burned out of control. Fire shadows have been documented downwind of lakes and other non-burning features (Heinselman, 1996).

\section{Discussion}

The treatment of wildlands for fire hazard reduction is both costly (e.g., Hiers et al., 2003; Keane et al., 2003; Lynch and Mackes, 2003) and controversial. However, in areas of high risk, such as the ponderosa pine type where return times for fire are short (Everett et al., 2000) or where extensive contiguous forest can produce fires exceeding 100,000 acres, it is imperative that some sort of action be taken.

The simulation results here have implications for forest management and restoration efforts. The ponderosa pine forest of the Uinkaret Mountains (Arizona) were placed under a fire regime restoration plan beginning in 1995 (Friederici, 2003). About 18\% of the 17,000 acres was to be treated to reduce fuels. According to the results of the simulations conducted here, the $18 \%$ treatment level is below the $30 \%$ threshold for fireproofing the landscape if done randomly. However, this amount is sufficient if high-risk areas (e.g., where spotting may originate) are treated first or if compartmentation is used. The $18 \%$ figure might also be largely effective if the fire shadow effects documented above occur with the typical fire on this forest.

We can also consider the effects of typical forest management. If stands are thinned and treated for fuels as part of silvicultural management, and this thinning reduces fire hazard in the stands for 10 years (in fact, it can be longer, see Fiedler and Keegan, 2003), the threshold for creating a fireproof (or fire-tolerant) forest is easily passed, depending on the degree of 
risk reduction created by thinning. Silvicultural systems for ponderosa pine that keep the stand open, such as group selection cuttings, will also create conditions that prevent crown fire and perhaps even prevent fire spread. These results suggest that there may be an economic value to commercial forest management in terms of fire prevention (or reduction in fire size or fire economic losses) that has not been properly taken into account in the planning process (it is not currently, according to Sessions et al. (1999)).

In both cases, we see that creating a firesafe landscape may be feasible either with available restoration funds or by efficient utilization of commercial forestry (or both) if spatial aspects of fire spread prevention are kept in mind. If topography plays a major role in fire spread on a particular landscape (Heyerdahl et al., 2001), leverage can be achieved by focusing on locations that cause the most fire spread by spotting and creation of fire storms.

The usage of the term "fireproof" or "firesafe" here should not be taken to mean that fire is excluded from the landscape. What is prevented is the spread of fires to giant sizes. In fact, with bulkheads it both becomes safer to do controlled burning, since fire escape cannot produce a catastrophic fire, and to let natural fires burn, since again they cannot become too large.

Bevers et al. (2004) addressed the problem of creating firebreaks around communities using random treatments to make the firebreaks look more natural. They used percolation of the interface zone as the criterion for success in stopping fire from penetrating (i.e., the treated grid cells connect up from one end of the interface zone to the other, blocking fire penetration). Their result for a threshold of about 0.59 (the usual threshold for percolation) or higher (if treatments were clustered to look more natural) is much higher than the value derived here. The reason is that they assume totally untreated forest that may have a fire front, or in which fire approach could be from any location. Thus if the treated areas do not connect, fire can penetrate. In the present study a different case is being considered. When a fire is started at a random location on a map with some degree of treated stands, it does not matter if the entire map percolates (untreated stands are connected somewhere from one side to the other) but only what the local neighborhood looks like. If the fire starts in a locality that is cut off from the rest of the forest, then only that local area can burn. That is, percolation is a universal property of the map, but average fire size is a property of the distribution of cluster sizes. As more stands (cells) are treated, the number of disconnected untreated clusters goes up, and average fire size goes down. Even a fire that burns all the way across the map on a percolating untreated cluster does not burn the whole map, because much of the map is unreachable by the fire.

The results obtained in this study have heuristic value and are not strictly predictive. The thresholds and responses of real forests can be calculated for realistic landscapes using fire simulators (e.g., Finney and Cohen, 2003). The qualitative results should hold, however. An extension of these results would be to link such realistic simulators with optimization tools (e.g., Hof and Omi, 2003) to find least-cost forest management plans. Such an endeavor is currently limited by a lack of guidance for formulating the optimization problem in terms of what goal structure should be achieved to help reduce fire risk (Hof and Omi, 2003). The results of this study suggest that the spatial pattern of the forest may be the key to achieving risk reduction at reasonable cost.

\section{References}

Agee, J.K., 1998. The landscape ecology of western forest fire regimes. Northwest Sci. 72, 24-34 (Special issue).

Agee, J.K., 2002. The fallacy of passive management. Conserv. Biol. 3 (1), 18-25 (Winter).

Armstrong, G.W., Cumming, S.G., 2003. Estimating the cost of land base changes due to wildfire using shadow prices. Forest Sci. 49 (5), 719-730.

Bevers, M., Omi, P.N., Hof, J., 2004. Random location of fuel treatments in wildland community interfaces: a percolation approach. Can. J. Forest Res. 34, 164-173.

Casagrandi, R., Rinaldi, S., 1999. A minimal model for forest fire regimes. Am. Nat. 153 (5), 527-539.

Clarke, K.C., Brass, J.A., Riggan, P.J., 1994. A cellular automaton model of wildfire propagation and extinction. Photogramm. Eng. Remote Sens. 60, 1355-1367.

Everett, R.L., Schellhaas, R., Keenum, D., Spurbeck, D., Ohlson, P., 2000. Fire history in the ponderosa pine/Douglas-fir forests on the east slope of the Washington Cascades. Forest Ecol. Manage. 129, 207-225.

Fiedler, C.E., Keegan, C.E., 2003. Reducing crown fire hazard in fire-adapted forests of New Mexico. In: USDA Forest Service Proceedings, RMRS-P 29. pp. 39-48. 
Finney, M.A., 2001. Design of regular landscape fuel treatment patterns for modifying fire growth and behavior. Forest Sci. 47, 219-228.

Finney, M.A., Cohen, J.D., 2003. Expectation and evaluation of fuel management objectives. In: USDA Forest Service Proceedings, RMRS-P 29. pp. 353-366.

Foster, T., 1976. Bushfire: History, Prevention, Control. Reed, Sydney, Australia.

Friederici, P., 2003. Healing the region of pines: forest restoration in Arizona's Uinkaret Mountains. In: Friederici, P. (Ed.), Ecological Restoration of Southwestern Ponderosa Pine Forest. Island Press, Washington, DC (Chapter 12).

Heinselman, M.L., 1996. The Boundary Waters Wilderness System. University of Minnesota Press.

Hessburg, P.F., Agee, J.K., 2003. An environmental narrative of inland northwest United States forests, 1800-2000. Forest Ecol. Manage. 178, 23-59.

Hessburg, P.F., Smith, B.G., Salter, R.B., Ottmar, R.D., Alvarado, E., 2000. Recent changes (1930s-1990s) in spatial patterns of interior northwest forests, USA. Forest Ecol. Manage. 136, 53-83.

Heyerdahl, E.K., Brubaker, L.B., Agee, J.K., 2001. Spatial controls of historical fire regimes: a multiscale example from the interior west. USA Ecol. 82 (3), 660-678.

Hiers, J.K., Laine, S.C., Bachant, J.J., Furman, J.H., Greene Jr., W.W., Compton, V., 2003. Simple spatial modeling tool for prioritizing prescribed burning activities at the landscape scale. Conserv. Biol. 17, 1571-1578.

Hirsch, K., Kafka, V., Tymstra, C., McAlpine, R., Hawkes, B., Stegehuis, H., Quintilio, S., Gauthier, S., Peck, K., 2001. Firesmart forest management: a pragmatic approach to sustainable forest management in fire-dominated ecosystems. Forest. Chron. 77 (2), 357-363.

Hof, J., Omi, P., 2003. Scheduling removals for fuels management. In: USDA Forest Service Proceedings, RMRS-P 29. pp. 367-378.

Hummel, S.S., Barbour, R.J., Hessburg, P.F., Lehmkuhl, J.F., 2001. Ecological and financial assessment of late-successional reserve management. Research Note PNW-RN-531. Pacific Northwest Research Station, USDA Forest Service.

Keane, R.E., Cary, G.J., Parsons, R., 2003. Using simulation to map fire regimes: an evaluation of approaches, strategies, and limitations. Int. J. Wildland Fire 12, 309-322.

Lefort, P., Gauthier, S., Bergeron, Y., 2003. The influence of fire weather and land use on the fire activity of the Lake Abitibi area, eastern Canada. Forest Sci. 49 (4), 509-521.

Li, C., Ter-Mikaelian, M., Perera, A., 1997. Temporal fire disturbance patterns on a forest landscape. Ecol. Model. 99, 137-150.
Lynch, D.L., Mackes, K., 2003. Costs for reducing fuels in Colorado forest restoration projects. In: USDA Forest Service Proceedings, RMRS-P 29. pp. 167-175.

McIver, J.D., Adams, P.W., Doyal, J.A., Drews, E.S., Hartsough, B.R., Kellogg, L.D., Niwa, C.G., Ottmar, R., Peck, R., Taratoot, M., Torgerson, T., Youngblood, A., 2003. Environmental effects and economics of mechanized logging for fuel reduction in northeaster Oregon mixed-conifer stands. Western J. Appl. Forest. 18 (4), 238-249.

Moore, M.M., Covington, W.W., Fule, P.Z., 1999. Reference conditions and ecological restoration: a southwestern ponderosa pine perspective. Ecol. Appl. 9, 1266-1277.

Omi, P.N., Martinson, E.J., 2002. Effects of fuels treatments on wildfire severity. Final Report. Joint Fire Sciences Program. Colorado State University, Fort Collins, CO.

Parsons, D.J., Van Wagtendonk, J.W., 1996. Fire research and management in the Sierra Nevada. In: Halvorson, W.L., Davis, G.E. (Eds.), Science and Ecosystem Management in the National Parks. University of Arizona Press, Tucson (Chapter 3).

Pollet, J., Omi, P.N., 2002. Effect of thinning and prescribed burning on crown fire severity in ponderosa pine forests. Int. J. Wildland Fire 11, 1-10.

Schoenberg, F.P., Peng, R., Huang, Z., Rundel, P., 2003. Detection of non-linearities in the dependence of burn area on fuel age and climatic variables. Int. J. Wildland Fire 12, 1-6.

Sessions, J., Johnson, K.N., Franklin, J.F., Gabriel, J.T., 1999. Achieving sustainable forest structures on fire-prone landscapes while pursuing multiple goals. In: Mladenoff, D.J., Baker, W.L. (Eds.), Spatial Modeling of Forest Landscape Change: Approches and Applications. Cambridge University Press, Cambridge, pp. 210-255.

Turner, M.G., Romme, W.H., Gardner, R.H., 1999. Prefire heterogeneity, fire severity, and early postfire plant reestablishment in subalpine forests of Yellowstone National Park, Wyoming. Int. J. Wildland Fire 9 (1), 21-36.

Van Wagtendonk, J.W., 1995. Large fires in wilderness areas. In: Brown, J.K., et al. (tech. coord.), Proceedings of the Symposium on Fire in Wilderness and Park Management. USDA For. Serv. Gen. Tech. Rep. INT-GTR-320. pp. 113-116.

Vines, R.G., 1981. Physics and chemistry of rural fires. In: Gill, A.M., Groves, R.H., Noble, I.R. (Eds.), Fire and the Australian Biota. Canberra Australian Academy of Science, Canberra, Australian Capital Territory, pp. 129-149.

Von Niessen, W., Blumen, A., 1986. Dynamics of forest fires as a directed percolation model. J. Phys. A: Math. Gen. 19, L289-L293.

Whelan, R.J., 1995. The Ecology of Fire. Cambridge University Press, Cambridge, UK, 316 pp. 